\title{
CUSTOMER SATISFACTION AS A MEDIATOR ON THE IMPACT OF SERVICE INDICATIONS IN INTERNATIONAL BUSINESS IN THE LIGHT OF SOCIAL MEDIA
}

\author{
Dr. Noreen Aleem \\ Assistant professor \\ Sindh Madressatul Islam University \\ Karachi - Pakistan \\ noreen.aleem@smiu.edu.pk \\ Dr. Masroor Khanam \\ Assistant Professor \\ Department of Mass communication, \\ Federal Urdu University Art's Science \& Technology Karachi. \\ masroor.khanam@fuuast.edu.pk \\ Irfan Ul Haque \\ Ph.D Scholar \\ Greenwich University \\ Karachi-Pakistan \\ irfan3323@gmail.com
}

\begin{abstract}
This article's main aim is to investigate the dimensions of quality service, which is one of the greatest difficulties confronting the banking sector, and even to enhance quality of service is now essential for the financial market. The notion of service quality will be examined while evaluating the link between service quality and client satisfaction. Service quality is the key aspect in assessing a productive bank's success. The SERVQUAL dimensions may be measured with regard to service quality, as the present study uses a model to estimate service quality in the Karachi bank sector, Pakistan. The essential aspects of the performance metrics are service quality and client loyalty. The characteristics of the quality of service are strongly related and are also valid in the banking industry in question for customer loyalty. Insights into social media research in fields such as sociology, economics and psychology have led to significant advances. In contrast, ideas of social networks remain more limitedly integrated into




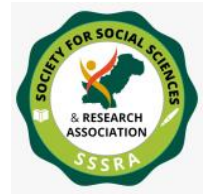

Pak. Journal of Int'L Affairs, Vol 4, Issue 2 (2021)

Customer Satisfaction as A Mediator ...

international business study. This special issue aims to encourage future worldwide social media research. We also point to a few prospects for the future in order to emphasise the potential to leverage marketing and ideas in social media to promote worldwide research and knowledge. Of 200 questionnaires issued, research results revealed that over 90 per cent of clients are loyal to banking services in Karachi, Pakistan; customer loyalty is affected by reliability, response, tangibility, sympathy and validity, although about 10 per cent are dissatisfied with the quality of service co-workers.
\end{abstract}

Keywords: Service quality, customer satisfaction, customer loyalty, banking, indications of service.

\title{
1.1 INTRODUCTION
}

Since the beginning of the 21st century, quality of service has become very important to the extent that the need for and improvement of the quality of service has become mandatory for the current consumer market. Researchers have been continuously conducting studies on the quality of service. According to Mostafa and Eneizan (2018), firm performance relies on effective and better quality of service levels. Awan, Bukhari, and Iqbal (2011) argued that customer satisfaction and quality of service have the same characteristics. Moreover, Raza et al. (2015) linked the quality of service level of the banking corporation to customer satisfaction. Globally, several researchers have assigned non-identical service sectors that recognize the different angles of service quality affecting customer loyalty. Technology, infrastructure regulations are some other factors also identified that affect the performance of the overall banking corporation. Advanced banking regulation is being implemented in the overall banking corporation for globalized functioning. Due to the frequent adoption of continuous improved regulations and reforms in the financial corporation, competition among banks has become more intensive (Matar and Eneizan, 2018). Banks are also adopting more advanced technology that leads the banking sector to improve the quality of service and thus to gain a competitive advantage.

The firms aim to meet the customer requirements on an exceptional level which can only be done by providing premium quality services to its customers in the service corporation. Different methods are being adopted by service industries on the different quality of service dimensions that help firms to meet customer demands effectively. By providing an effective quality of service level, firms not only fulfil the customer demands but also maintain the loyalty of the customer which benefits the firm in the long run. An 


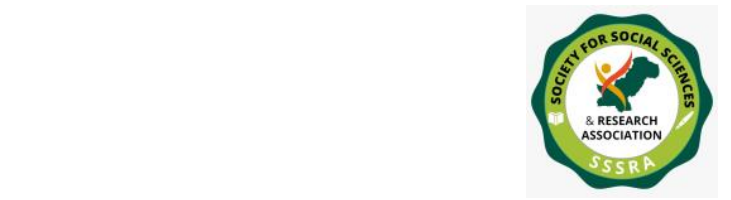

overview of the different dimensions of quality of service over consumer satisfaction of banks in Karachi, Pakistan is a key point of this study.

\subsection{BACKGROUND STUDY}

According to Raza et al., (2015) and many other researchers relate to the quality of service in their past studies they indicate that the customer and quality of service are key indicators for the service sector. It is also one of the theories which relate to the quality of service and customer satisfaction. Besides, the quality of service is indispensable for the banking sector. (Awan, 2011).

As stated by different authors that the interpretation and implementation of the service and quality relationship model and its dimensions, many researchers in previous studies had criticized it. By mentioning problems in dimensions of the SERVQUAL instrument; researchers discovered it for perception, expectations, and gap scores because this instrument is uncertain. However, the model SERVQUAL dimensions have been used by organizations for studies in the development of the literature (Parasuraman et al., 1988). Regardless of criticism, SERVQUAL dimensions can be measured for quality of service (Buttle, 1996).

\subsection{PROBLEM STATEMENT}

For the last few years, it has been stressed that the quality of service attributes are strongly correlated with customer satisfaction. (Gera, 2011) and there are sufficient researchers exists that descriptively analyze the variables relationships in the service corporation but the studies done with regards to the banking corporation in Karachi are not sufficiently found. It has also been recognized in many areas of research that responsiveness does not have a considerable impact on customer satisfaction

\subsection{RESEARCH OBJECTIVE}

The following are the specific objective of this study which we will achieve through analysis of;

1. To ascertain a constructive correlation between reliability and the loyalty of the customer.

2. To ascertain a constructive correlation between responsiveness and the loyalty of the customer.

3. To ascertain a constructive correlation between assurance and the loyalty of the customer.

4. To ascertain a constructive correlation between empathy and the loyalty of the customer. 


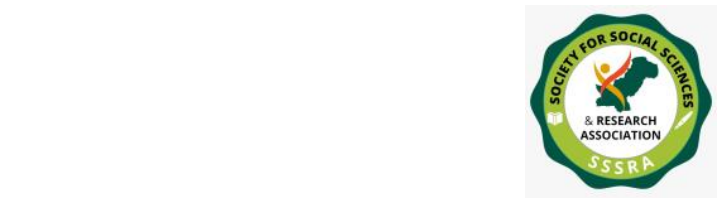

Pak. Journal of Int'L Affairs, Vol 4, Issue 2 (2021)

Customer Satisfaction as A Mediator ...

5. To ascertain that there is a facilitating impact of the customer satisfaction between tangibility and the loyalty of the customer.

\subsection{SCOPE OF RESEARCH}

Accordingly, the present research is committed to conducting in Karachi, Pakistan. The population of this study is focused on those customers who are utilizing the bank services in Karachi, Pakistan. As stated in the context of the study, it is the customers who recognize the quality of the service. On this note, the most important respondents in this research are the service users of the banks.

\subsection{CONCEPTUAL GAP}

To measure the perceived service quality and product, there is no standard scale available to the public, particularly for banks, this is the reason that banking service issues are still under constant discussion. Despite the banking sector in all other sectors such as (education, hospital, travel, and tourism), the SERVQUAL dimensional instrument has been widely used (Oldfield and Baron, 2000).

\subsection{CONTRIBUTION OF THE STUDY}

The underlying framework developed for this study, with particular reference to the customer satisfaction and the loyalty of the customer in the banking sector of Pakistan, is lacking in previous studies. This study aims to contribute to Pakistan's banking sector by analyzing customer satisfaction with its five-dimensional quality of service. The study explores the impact of each dimension of quality of service on Pakistan's banking corporation. This will have a positive effect and will have a crucial impact on the banking sector, recognizing the significance of customer service and loyalty.

\section{Literature Review}

\subsection{The customer satisfaction and the loyalty of the customer:}

Customer's loyalty is one of a travel company's most explored areas due to its participation in a travel company's performance and rising influence (Dyer et al., 2007). Theoretically, client loyalty was defined as a feeling that consumers experience when they buy. Contrary to the fundamental psychological interest of acknowledgements, customer loyalty is considered full of reactions to products or management. The consumer is intended to be happy with the experience to generate a sense of pleasure when compared with a desire (Choi and $\mathrm{Chu}, 2001$ ). Realizing the customer at a travel agency is the condition of the visitor's after-visit feeling. The holiday customers' loyalty aim is the amount of enjoyment that travellers typically feel, resulting in visitors experiencing meeting tourists' "wants, wishes and requirements" (Chen \& Tsai, 2007). 


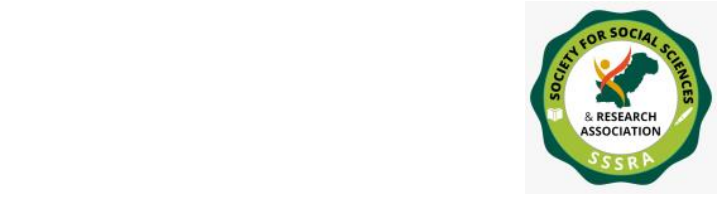

Consumer loyalty goes past the assistance experience that a customer experienced. It joints esteem judgment and correlation with beginning desire for what the administration quality ought to be; regularly based it is a general examination between the worth that the customers see and the value that they pay (Rust and Zahorik, 1993).

\subsection{The customer satisfaction}

It is vital to understand the happiness of the consumer. If the happiness of the consumer is only attributed to a happy customer, then this is unfair. Customer satisfaction is commonly used as a wider phrase in business. Companies analyse their product and service capabilities, by applying the same idea as a banking company, to satisfy their consumer expectations. The customer's response to the whole consumption of items or services might be called satisfaction. "It is a question of judgement that a product or service feature, or a product or service itself, offers a satisfactory degree of consumer pleasure" is defined by Oliver (1981). Researchers like Kotler et al. (1996) characterised customer satisfaction "as a person's emotional condition as the consequence of a comparison of the results and expectations for product and service consumption."

\subsection{Quality of service}

Company efficiency and business as a strategic strategy are used to attain and maintain the requisite quality levels (Anderson and Zeithaml, 1984). Over numerous decades, various scholars have investigated and defined quality. Crosby has considered quality "conformity to standards" (1984). Juran (1988) interpreted it as "fitness for usage" and "quality for the consumer". The quality of the service environment, as it can be described as experience components, is more challenging to evaluate and to measure, according to Parasuraman, Zeithaml and Berry (1985).

\subsection{Relationship between customer satisfaction and quality service}

When studying customer pleasure, we usually emphasise the concept of quality of service. Improved client satisfaction improves the quality of service. In various research studies in diverse circumstances the relationship between service quality and customer satisfaction is therefore noted. The importance of customer happiness in terms of service quality was acknowledged in Chow \& Luk (2005). Cronin and Taylor have described the positive link between service quality and customer satisfaction (1992). The Bank Firm, for example, did not have a standard measurement aspect to evaluate banking company success, which means the Bank Company is solely dependent on the quality of its service model for its performance to be evaluated. And please your customers. Although many studies have investigated the link between service quality and customer happiness, in particular Zeithaml and Bitner (2000). 


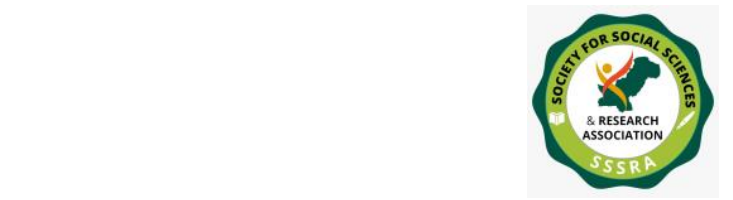

Pak. Journal of Int'L Affairs, Vol 4, Issue 2 (2021)

Customer Satisfaction as A Mediator ...

\section{Quality of service Dimensions / SERVQUAL Model}

Parasuraman et al. (1988) recommended that the quality of service characteristics referred to above be both clearer and more broadly decreased to 5. Parasuraman et al (1988) carefully explain every factor of service quality that might have an influence in the SERVQUAL model on customer perception and satisfaction. These five traits are reliable, tangible, reliable and compassionate. Detailed insights into service quality elements, its characteristics and client pleasure are provided here.

\subsubsection{Tangibility and the customer satisfaction}

The physical reality or presence is referred to the tangibility of the things which are empirically verified by the human five senses. Tangibility is considered an important key indicator of customer satisfaction when it relates to the service sector. Being the seller of intangible products, service industries must have to make available more tangible offerings to satisfy their customer needs. Parasuraman et al., (1985) describe tangibility as "the appearance of physical facilities, personnel, equipment, and written records." The tangibility of the service sector includes highly advanced equipment, a pleasant environment, and well-trained staff. These tangible elements help effectively maintain customer loyalty and satisfaction. Due to less importance is given to these tangibles, the customer shifts are more often observed in the service corporation especially banks. Tangibility is considered as the basis of customer satisfaction, sustainable growth, and differentiation competency. Long-term relationships and customer retention are acquired by offering both tangible and intangible products today. The combination of both tangibles and intangibles dimensions adds more value and results in an above-average return for the organization. Paul et al. (2016) also stated that ambience, advanced technological equipment, well-trained, motivated employees, and their communication skills can lead the organizations towards more profitability.

H1 = Service Tangibility has an expectant connection with customer satisfaction which has an expectant connection with the loyalty of the customer.

\subsection{Reliability and the customer satisfaction}

Parasuraman \& Zeithaml (1988) described reliability as the firm competency to resolve customer ambiguities and problems efficiently and the management of the customer relations concerning the customer perspective. Reliability is also defined as the timely and accurate service delivery as per decided terms with the customers. Effective and efficient communication between the client and the company creates differentiation for clients. Therefore, a company that effectively communicates its offer and promises is more preferable for customers (Kainat, 2017). Reliability is also a key component in 


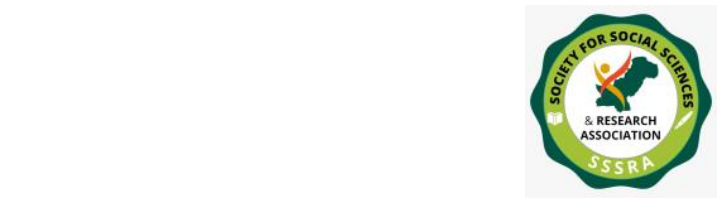

defining your consumers' long-term connection (Parasuraman and Zeithaml, 1988). Previous research showed that customer satisfaction is affected by dependability. This is also one of the main elements of the quality of service (Kashif et al., 2015). The use of highly sophisticated technology, which offers a competitive edge for effective and efficient operation, enhances business reliability.

\subsubsection{Responsiveness and the customer satisfaction}

Responsiveness is also one of the crucial dimensions of the quality of service performed by firms to ensure enhanced customer satisfaction (Ding et al, 2017). Descriptive guidance provided to the customers by the Firm's representative when it's needed is the part of responsiveness strategy of firms. It has been observed that highly motivated employees lead to provide more customer satisfaction because they provide necessary information to the customers without wasting their time, the implications of responsiveness on the customer satisfaction and the loyalty of the customer are therefore positive (Alkhawaldeh \& Eneizan, 2018). The consumers will not focus on previous bad experiences if they get an efficient response and are fulfilled largely by firms. Responsiveness also helps to maintain the security position of firms in the market. In other words, responsiveness can be defined as the Firm response to the customers' inquiries and solutions or responses to those inquiries. In the broader concept responsiveness relates to the firm understanding of the customer demands and how those demands can be fulfilled effectively and efficiently (Parasuraman \& Zeithaml, 1988). It has been recognized not only as an essential dimension of quality of service but also as having a positive impact on satisfying the customer. If firms motivate employees to be more sensitive and approachable to customer inquiries, the firm will acquire higher customer satisfaction because the employees are the main key element of this dimension of quality of service which directly affects customer satisfaction (Al-Azzam, 2015). Employee's behaviours and attitudes are responsible for the firm's image in front of its customers when it comes to responsiveness. Firms must therefore be more careful when it comes to direct customer dealing and must provide their people with the required training and development sessions. It will therefore lead the firm towards the acquisition of more the customer satisfaction (Loke et al., 2011).

$\mathrm{H} 3=$ Service Responsiveness has an expectant connection with the customer satisfaction which has an expectant connection with the loyalty of the customer.

\subsubsection{Assurance and the customer satisfaction}

Paul et al., (2016) described the characteristics of assurance concerning the manager's and employee's friendly learning behaviour and attitude. Assurance is developed within clients by employees when they act with humility and courtesy towards clients in this 


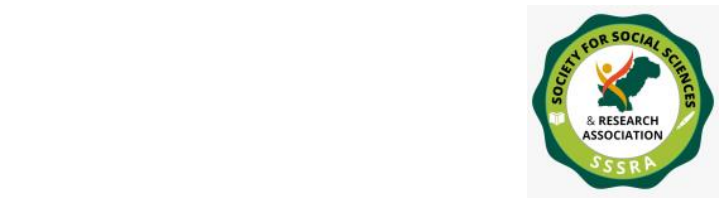

way, assuring them that they will be available at all times to help them (Khan and Fasih, 2014). Knowledge and courtesy of employees are considered to be the elements that promote trust in the minds of customers (Parasuraman and Zeithaml, 1988). Customer trust in the company has a direct positive influence on customer satisfaction, as previous studies show. Therefore, customer trust in employees leads customers to buy more and as a result has a positive impact on customer satisfaction. Parasuraman et al. (1988) rated assurance as one of the notable dimensions of service quality.

$\mathrm{H} 4=$ Service Assurance has an expectant connection with customer satisfaction which has an expectant connection with the loyalty of the customer.

\subsubsection{Empathy and the customer satisfaction}

Empathy is also one of the essential dimensions of quality of service that can be described as the employees' skills to captivate the attention of the customer when dealing individually (Paul et al., 2016). Moreover, the employee capability to offer a differentiated product as compared to its competitors, should not impact the loyalty of the customer. For instance, the flexibility of working hours of the firm, personal recommendation given to the customers, and the understanding of the customer need and in how many ways it can adequately be fulfilled. All these actions taken by the firm have a greater positive impact as it leads to improved communication between the firm and the customers (Alkhawaldeh et al., 2017). Empathy can also be described as firm capability. To resolve the customer's ambiguities and problems (Parasuraman \& Zeithaml, 1988). Thus firm empathetic behaviour towards resolutions of the customer's problems is most important to keep the customer satisfaction on a high level. Studies have been conducted to analyze the positive impact of empathic behaviour on customer satisfaction. Empathic attitude and behaviour not only improve consumer satisfaction but also maintain a competitive advantage for companies (Flick, 2015).

H5= Service Empathy has an expectant connection with customer satisfaction which has an expectant connection with the loyalty of the customer.

\section{METHODOLOGY}

\subsection{RESEARCH DESIGN}

The present study is quantitative research. For the study, data is gathered at a single time and it reflects all characteristics of the population, therefore, this study is categorized as cross-sectional research. The questionnaire attached as Annex-I was adopted from Alabboodi (2019) and based on a 5-point Likert type scale 5= Strongly Agree, 4= Agree, $3=$ Neutral, $2=$ Disagree, and 1= strongly Disagree. 


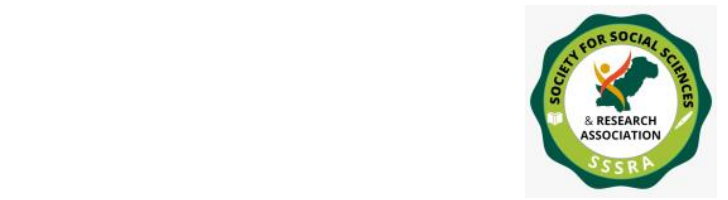

Customer Satisfaction as A Mediator ...

\section{2}

POPULATION SAMPLING

A sample is described as a smaller set of information that is chosen and/or chosen from a large population with the aid of the usage of a predefined resolution method. These factors are known as pattern points, sampling units, or observations. Creating a pattern is an efficient method of conducting lookup as in most cases, it is impossible or very steeply-priced time consuming to research the entire population and therefore learning the pattern provides insights that can be utilized to the whole population.

\subsection{RESEARCH SAMPLE SIZE}

To gain representative data from an entire population, the target population is 250 Karachi residents, and in the business context, Karachi is recognized as the most business-friendly cosmopolitan city in Pakistan and the commercial hub of Pakistan's banking and financial services sector. Karachi is the provincial capital of Sindh and the largest city in Pakistan. The population can be approached either online or on-ground basis.

\subsection{SAMPLE TECHNIQUE}

In the current study, the non-probability sampling technique of convenience is used because the target population consists of randomly chosen quality of service, therefore, using this technique would be most appropriate for this research. Also, the idea of using this technique has been supported by Hollensen (2019) who researched finance.

\subsection{RESEARCH INSTRUMENT}

The research instrument employed in this research is the Likert scale questionnaire, it is essential to measure the opinion or attitude of an interviewee towards a topic. This specific type of research is done in finance. The Questionnaire includes close-ended questions and it will be distributed online. The idea of using this Research Instrument has been supported by many of the past researchers who researched finance and numerous other fields.

\subsection{NOMINAL SCALE}

We should start with the most direct one to get it. Nominal scales are used for marking factors, with no quantitative regard. "Nominal" scales appear to be essentially be classified as "labels". Here are a couple of cases, observe that these scales are normally tip-top (no cover) and none of them has any mathematical significance. An incredible method to remember all of ordinarily that "nominal" sounds a section like "name" and apparent scales are somewhat similar to "names" or names.

What is your gender?

A. Male 
B. Female

What is your hair colour?

1. Brown

2. Black

3. White

4. Grey

5. Blonde

Where do you live?

1. Europe

2. Asia

\section{7}

\section{ORDINAL SCALE}

With ordinal scales, the organization of qualities is fundamental and significant, however, the differences between each are not recognized. Take a look at the schematic below. For each situation, we know that n. 4 is a better path than No. 3 or No. 2, but we have no idea and can not assess how much better it is. For representation, is the differentiation between "all right" and "Despondent" equivalent to the difference between "Glad" and "Upbeat"? We cannot describe.

\subsection{RESEARCH FRAMEWORK}

Given the current literature and available studies on the subject, we have adopted a framework proposed by Alabboodi (2019). The conceptual framework developed for our study is as follows:

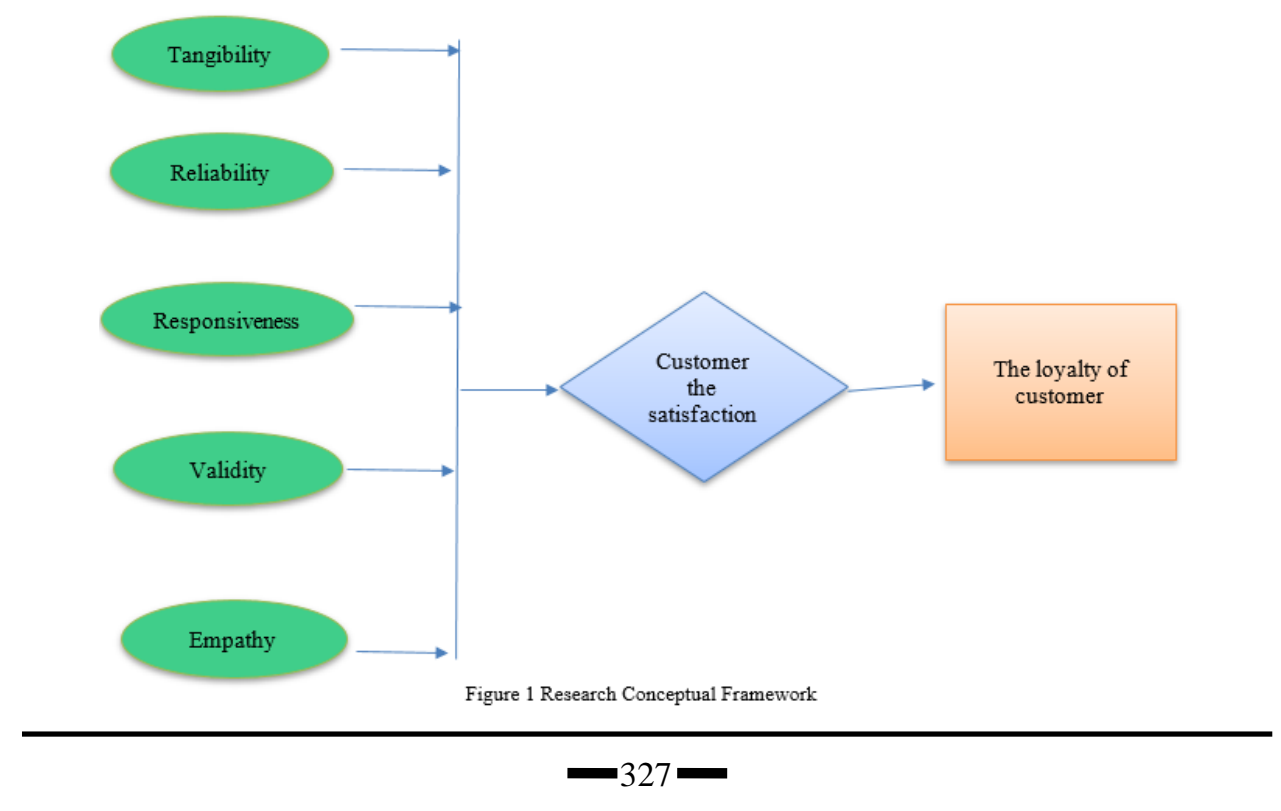




\subsection{HYPOTHESIS DEVELOPMENT}

As can be seen from the conceptual framework (figure 1), there is a link between the IVs, the mediator, and the DV. Based on this conceptual framework, hypotheses were designed are tested in the whole study and are elaborated at different stages of this research.

\section{Research Results \\ Respondent Profile}

The demographics of the study is shown in the table below:

The demographics of the study is shown in the table below:

\begin{tabular}{|l|l|l|}
\hline Variable & Description & Percentage \% \\
\hline \multirow{4}{*}{ Gender } & Male & 64.6 \\
\cline { 2 - 3 } & Female & 35.4 \\
\hline \multirow{5}{*}{ Age } & Less than 18 & 1.5 \\
\cline { 2 - 3 } & $18-30$ & 68.5 \\
\cline { 2 - 3 } & $30-50$ & 26.2 \\
\cline { 2 - 3 } & More than 50 & 3.8 \\
\hline \multirow{5}{*}{ Status } & Student & 19.2 \\
\cline { 2 - 3 } & Employed & 66.9 \\
\cline { 2 - 3 } & Unemployed & 2.3 \\
\cline { 2 - 3 } & Own Business & 10 \\
\cline { 2 - 3 } & Retired/Pension & 1.5 \\
\hline
\end{tabular}

The above data indicate that $64.6 \%$ of our respondents were male and $35.4 \%$ were female, which suggests that there is a very significant impact of male opinion on the survey results. One more implication of these statistics shows male dominance due to cultural norms.

The above statistics indicate that around $68.5 \%$ of our respondents are between 18 and 30 years old and $26.2 \%$ between 30 and 50 years old. The results imply that the large majority of users of banking institutions are in these demographics, which shape the results of our study and they are the majority target market for the banking sector.

\section{Response Rate}

The population covered for the study refers to customer banking services in Karachi, Pakistan. The random sampling methodology was employed to sample the required population. Online questionnaires have been distributed in our social circle due to the

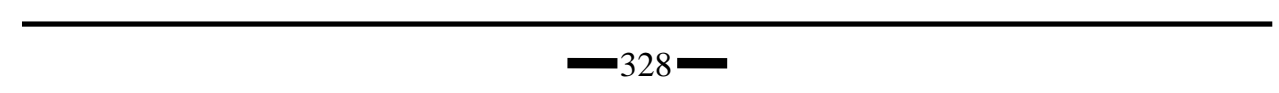


current situation. The response rate was 79\%. Due to limitations, 130 responses out of 111 were received that could be used for the research study.

\section{4: RESULTS AND DISCUSSIONS:}

We have used Microsoft Excel, online Google forms, and SPSS for analysis.

\subsection{STATISTICAL ANALYSIS:}

\subsubsection{Statistical Result}

4.1.1 Statistical Result

\begin{tabular}{|c|c|c|c|c|}
\hline Direct Relationships & Coefficient & T Stat. & Values & Result \\
\hline Service Assurance $>$ The customer satisfaction $(\mathrm{H} 1)$ & 0.547 & 7.363 & 0.00 & Accept H1 \\
\hline Service Empathy $>$ The customer satisfaction (H2) & 0.317 & 3.894 & 0.00 & Accept $\mathrm{H} 2$ \\
\hline Service Responsiveness $>$ The customer satisfaction $(\mathrm{H} 3)$ & 0.435 & 5.298 & 0.00 & Accept H3 \\
\hline Service Reliability $>>$ The customer satisfaction (H4) & 0.349 & 4.345 & 0.00 & Accept H4 \\
\hline 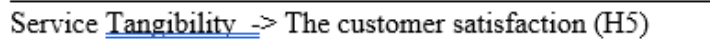 & 0.244 & 2.760 & 0.01 & Accept H5 \\
\hline The customer satisfaction-> The loyalty of the customer & & & & Accept H6 \\
\hline (H6) & 0.280 & 2.110 & 0.04 & \\
\hline
\end{tabular}

\section{Indirect Relationships}

\begin{tabular}{|c|c|c|c|}
\hline $\begin{array}{l}\text { Assurance }>\text { The customer satisfaction }>\text { The loyalty of } \\
\text { the customer (H9) }\end{array}$ & 0.153 & 0.03 & Accept H9 \\
\hline Empathy $>$ The customer satisfaction $>$ The loyalty of the & & & Reject $\mathrm{H} 10$ \\
\hline customer $(\mathrm{H} 10)$ & 0.023 & 0.14 & \\
\hline Responsiveness $>$ The customer satisfaction $>$ The loyalty & & & Reject H11 \\
\hline of the customer (H11) & 0.025 & 0.12 & \\
\hline $\begin{array}{l}\text { Reliability }>\text { The customer satisfaction }>\text { The loyalty of } \\
\text { the customer. (H12) }\end{array}$ & 0.079 & 0.04 & Accept H12 \\
\hline $\begin{array}{l}\text { Tangibility--> The customer satisfaction }>>\text { The loyalty of } \\
\text { the customer (H13) }\end{array}$ & 0.059 & 0.03 & Accept H13 \\
\hline
\end{tabular}

\subsubsection{Correlation Analysis:}

To calculate the relationship between these two variables we have used correlation analysis. The relationship among the independent and dependent variables is briefly explained by Karl Pearson r (Malhotra, 2010) as shown below. 


\section{Correlations}

\begin{tabular}{|c|c|c|c|c|c|c|c|}
\hline & & SA & SE & $\mathrm{SR}$ & SRL & ST & $\mathrm{CS}$ \\
\hline $\mathrm{SA}$ & Pearson & 1 & $.446^{* *}$ & $.337^{* *}$ & $.394^{* *}$ & $.413^{* *}$ & $.470^{* *}$ \\
\hline & Correlation & & & & & & \\
\hline & Sig. (2-tailed) & & .000 & .001 & .000 & .000 & .000 \\
\hline & $\mathrm{N}$ & 89 & 89 & 89 & 89 & 89 & 89 \\
\hline SE & Pearson & $.446^{* *}$ & 1 & $.753^{* *}$ & $.717^{* *}$ & $.627^{* *}$ & $.680^{* *}$ \\
\hline & Correlation & & & & & & \\
\hline & Sig. (2-tailed) & .000 & & .000 & .000 & .000 & .000 \\
\hline & $\mathrm{N}$ & 89 & 89 & 89 & 89 & 89 & 89 \\
\hline SR & Pearson & $.337^{* *}$ & $.753^{* *}$ & 1 & $.695^{* *}$ & $.527^{* *}$ & $.672^{* *}$ \\
\hline & Correlation & & & & & & \\
\hline & Sig. (2-tailed) & .001 & .000 & & .000 & .000 & .000 \\
\hline & $\mathrm{N}$ & 89 & 89 & 89 & 89 & 89 & 89 \\
\hline SRL & Pearson & $.394^{* *}$ & $.717^{* *}$ & $.695^{* *}$ & 1 & $.577^{* *}$ & $.710^{* *}$ \\
\hline & Correlation & & & & & & \\
\hline & Sig. (2-tailed) & .000 & .000 & .000 & & .000 & .000 \\
\hline & $\mathrm{N}$ & 89 & 89 & 89 & 89 & 89 & 89 \\
\hline ST & Pearson & $.413^{* *}$ & $.627^{* *}$ & $.527^{* *}$ & $.577^{* *}$ & 1 & $.641^{* *}$ \\
\hline & Correlation & & & & & & \\
\hline & Sig. (2-tailed) & .000 & .000 & .000 & .000 & & .000 \\
\hline & $\mathrm{N}$ & 89 & 89 & 89 & 89 & 89 & 89 \\
\hline CS & Pearson & $.470^{* *}$ & $.680^{* *}$ & $.672^{* *}$ & $.710^{* *}$ & $.641^{* *}$ & 1 \\
\hline & Correlation & & & & & & \\
\hline & Sig. (2-tailed) & .000 & .000 & .000 & .000 & .000 & \\
\hline & $\mathrm{N}$ & 89 & 89 & 89 & 89 & 89 & 89 \\
\hline $\mathrm{CL}$ & Pearson & $.449^{* *}$ & $.488^{* *}$ & $.435^{* *}$ & $.510^{* *}$ & $.572^{* *}$ & $.550^{* *}$ \\
\hline & Correlation & & & & & & \\
\hline & Sig. (2-tailed) & .000 & .000 & .000 & .000 & .000 & .000 \\
\hline & $\mathrm{N}$ & 89 & 89 & 89 & 89 & 89 & 89 \\
\hline
\end{tabular}




\section{Descriptive Statistics}

\begin{tabular}{l|r|r|r} 
& \multicolumn{1}{|c|}{$\begin{array}{c}\text { Std. } \\
\text { Mean }\end{array}$} & \multicolumn{1}{c}{ Deviation } & \multicolumn{1}{l}{ N } \\
\hline SA & 13.83 & 3.217 & 89 \\
\hline SE & 16.49 & 4.071 & 89 \\
\hline SR & 13.39 & 3.073 & 89 \\
\hline SRL & 17.22 & 3.176 & 89 \\
\hline ST & 15.00 & 2.743 & 89 \\
\hline CS & 14.51 & 2.817 & 89 \\
\hline CL & 17.00 & 2.751 & 89 \\
\hline
\end{tabular}

\subsubsection{Regression Analysis:}

To calculate the connection between variables we have used regression analysis. We have regressed the factors using the calculation to conclude the connection between independent variables and dependent variables.

\begin{tabular}{lr|r|r} 
& \multicolumn{3}{c}{ Descriptive Statistics } \\
& Mean & Std. Deviation & N \\
\hline CL & 17.00 & 2.751 & 89 \\
\hline SA & 13.83 & 3.217 & 89 \\
\hline SE & 16.49 & 4.071 & 89 \\
\hline SR & 13.39 & 3.073 & 89 \\
\hline SRL & 17.22 & 3.176 & 89 \\
\hline ST & 15.00 & 2.743 & 89 \\
\hline
\end{tabular}




\begin{tabular}{|c|c|c|c|c|c|c|c|}
\hline \multirow[b]{3}{*}{ Model } & \multicolumn{7}{|c|}{ Model Summary } \\
\hline & & & & Std. The & Char & nge Statistics & \\
\hline & $\mathrm{R}$ & R Square & $\begin{array}{l}\text { Adjusted R } \\
\text { Square }\end{array}$ & $\begin{array}{l}\text { error of the } \\
\text { Estimate }\end{array}$ & $\begin{array}{l}\text { R Square } \\
\text { Change }\end{array}$ & F Change & df1 \\
\hline 1 & $.643^{\mathrm{a}}$ & .414 & .379 & 2.169 & .414 & 11.720 & 5 \\
\hline
\end{tabular}

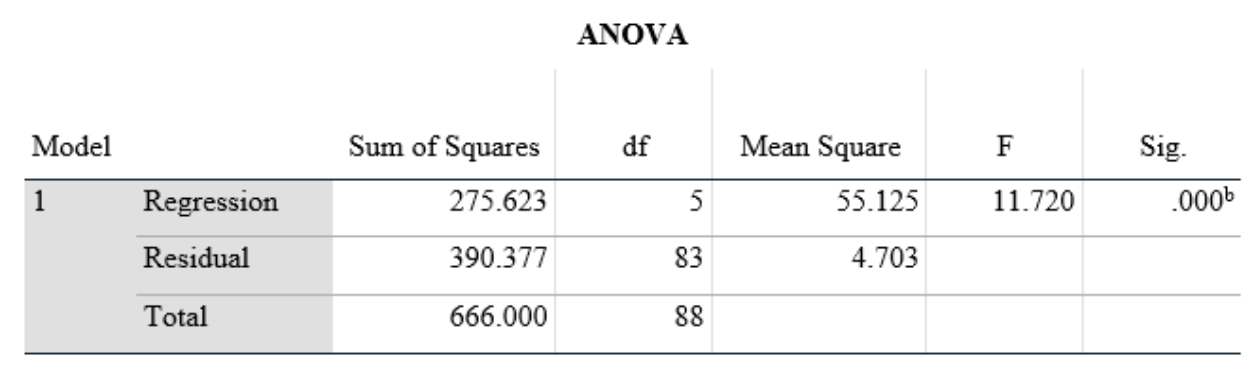

\section{Coefficients}

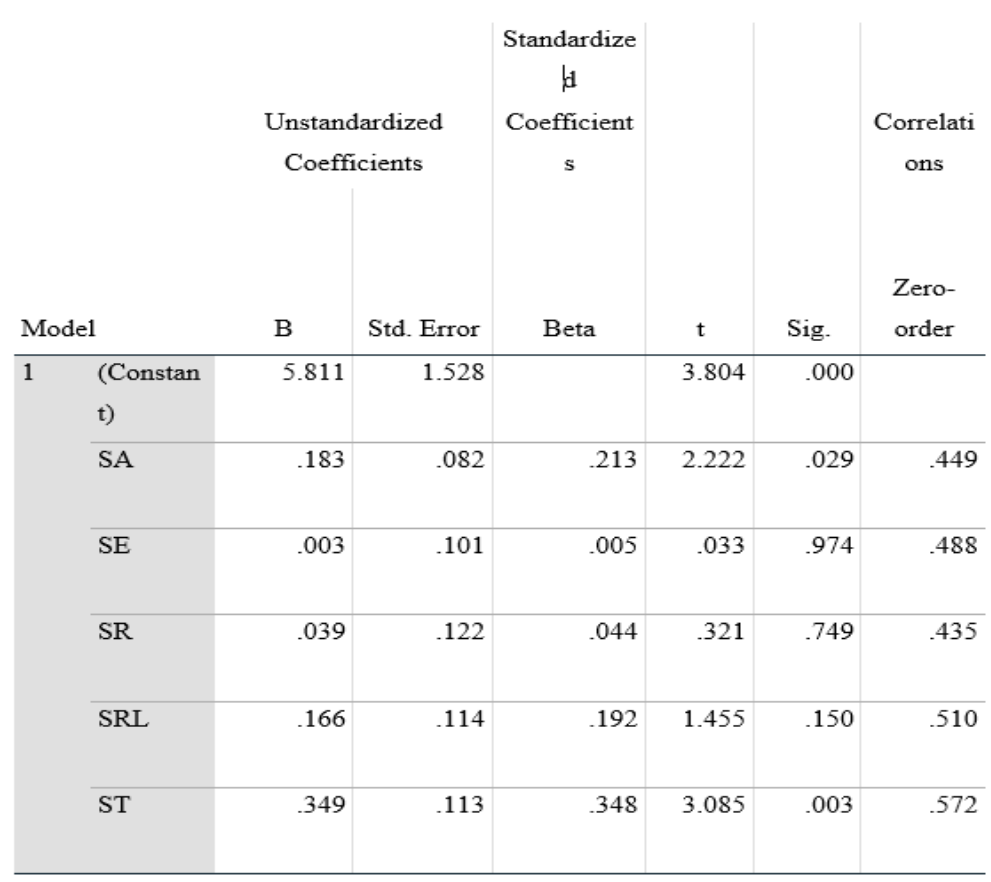




\begin{tabular}{|c|c|c|c|c|c|c|c|}
\hline \multicolumn{8}{|c|}{ Coefficient Correlations } \\
\hline Model & & & ST & SA & SR & SRL & SE \\
\hline \multirow[t]{10}{*}{1} & Correlations & ST & 1.000 & -.172 & -.039 & -.192 & -.275 \\
\hline & & SA & -.172 & 1.000 & .047 & -.089 & -.180 \\
\hline & & SR & -.039 & .047 & 1.000 & -.327 & -.471 \\
\hline & & SRL & -.192 & -.089 & -.327 & 1.000 & -.291 \\
\hline & & SE & -.275 & -.180 & -.471 & -.291 & 1.000 \\
\hline & Covariance & ST & .013 & -.002 & -.001 & -.002 & -.003 \\
\hline & & SA & -.002 & .007 & .000 & -.001 & -.002 \\
\hline & & SR & -.001 & .000 & .015 & -.005 & -.006 \\
\hline & & SRL & -.002 & -.001 & -.005 & .013 & -.003 \\
\hline & & SE & -.003 & -.002 & -.006 & -.003 & .010 \\
\hline
\end{tabular}

\section{Summary Item Statistics}

\begin{tabular}{|c|c|c|c|c|c|c|}
\hline & Mean & Minimum & $\begin{array}{c}\text { Maximu } \\
\mathrm{m}\end{array}$ & Range & $\begin{array}{l}\text { Maximum / } \\
\text { Minimum }\end{array}$ & Variance \\
\hline Item Means & 3.466 & 2.730 & 3.978 & 1.247 & 1.457 & .067 \\
\hline Item Variances & .846 & .611 & 1.186 & .575 & 1.941 & .026 \\
\hline Inter-Item Covariance & .292 & -.152 & .676 & .828 & -4.436 & .019 \\
\hline $\begin{array}{l}\text { Inter-Item } \\
\text { Correlations }\end{array}$ & .354 & -.175 & .769 & .944 & -4.392 & .026 \\
\hline
\end{tabular}




\section{Scale Statistics}

\begin{tabular}{l|r|r|r} 
Mean & Variance & Std. Deviation & N of Items \\
\hline 107.45 & 297.705 & 17.254 & 31 \\
\hline
\end{tabular}

\section{Reliability Statistics}

\begin{tabular}{|c|c|c|}
\hline $\begin{array}{c}\text { Cronbach's } \\
\text { Alpha }\end{array}$ & $\begin{array}{c}\text { Cronbach's } \\
\text { Alpha Based on } \\
\text { Standardized } \\
\text { Items }\end{array}$ & $\mathrm{N}$ of Items \\
\hline .942 & .944 & 31 \\
\hline
\end{tabular}

\section{CHARTS:}

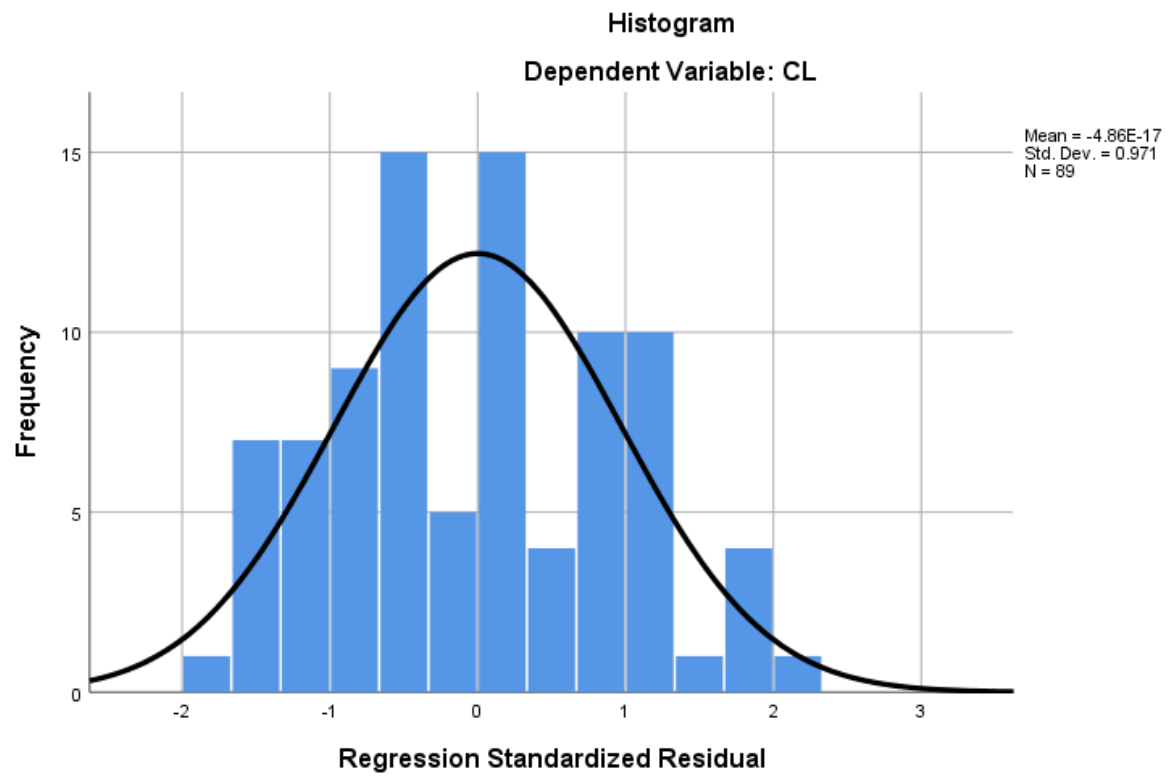




\section{Normal P-P Plot of Regression Standardized Residual}

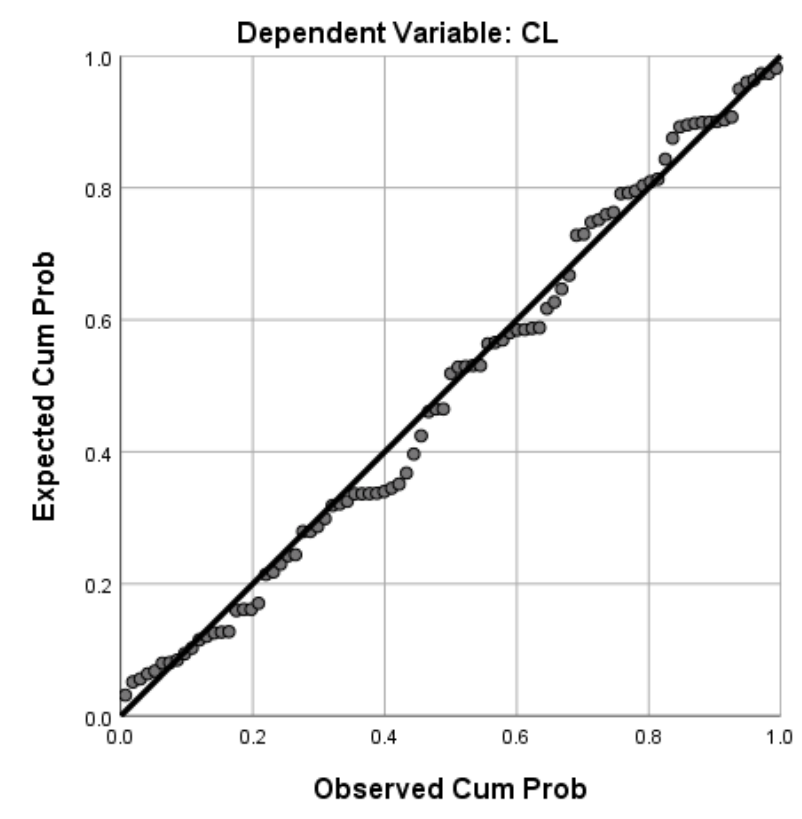

Partial Regression Plot

Dependent Variable: CL

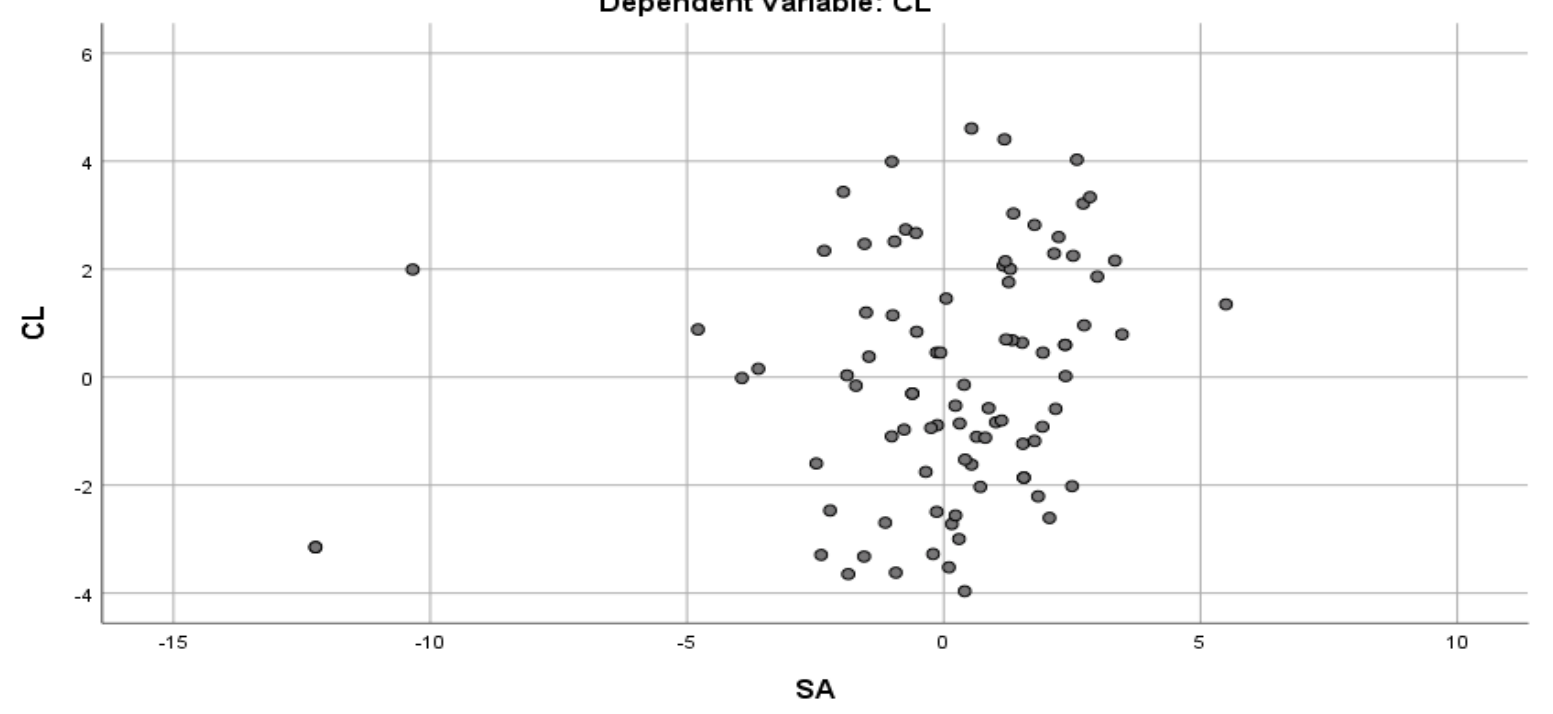




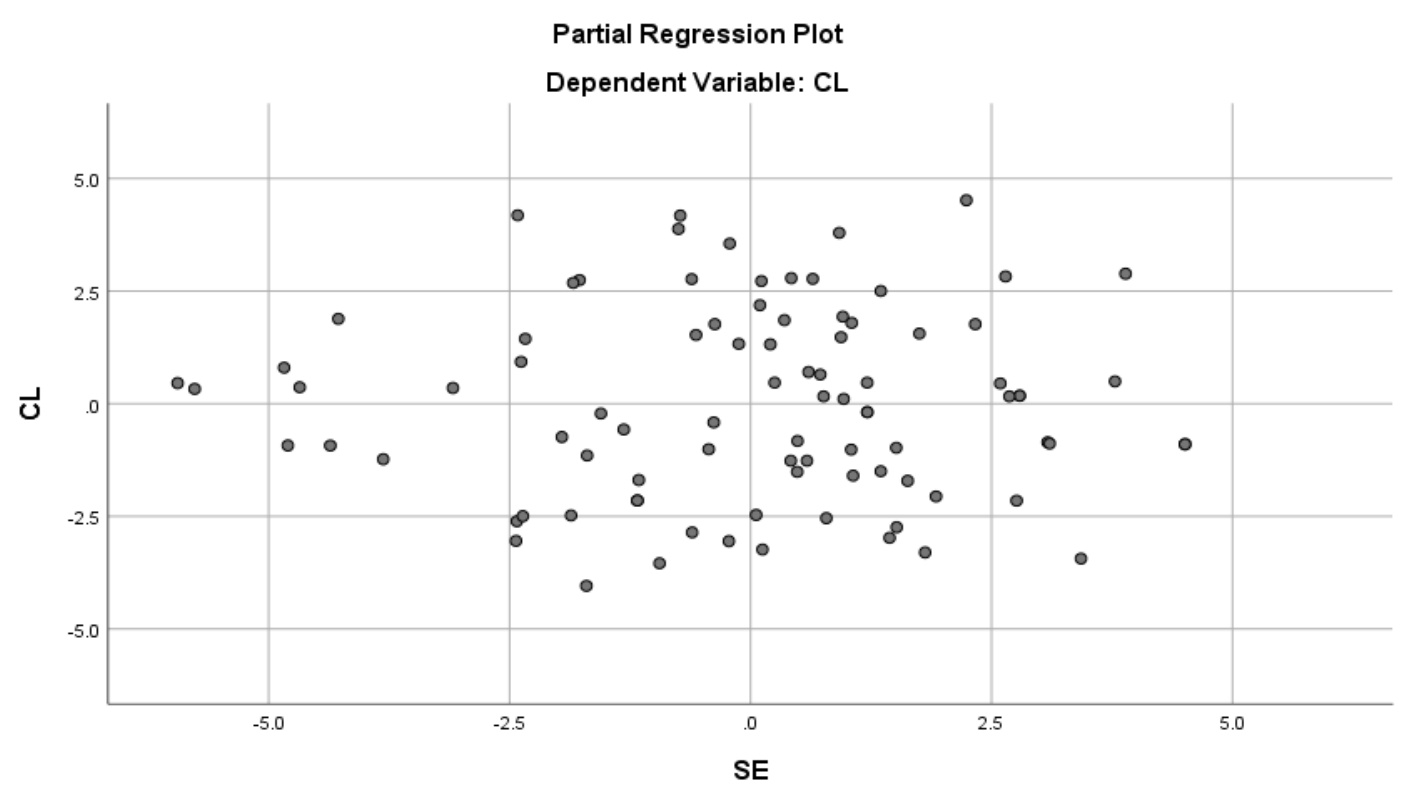



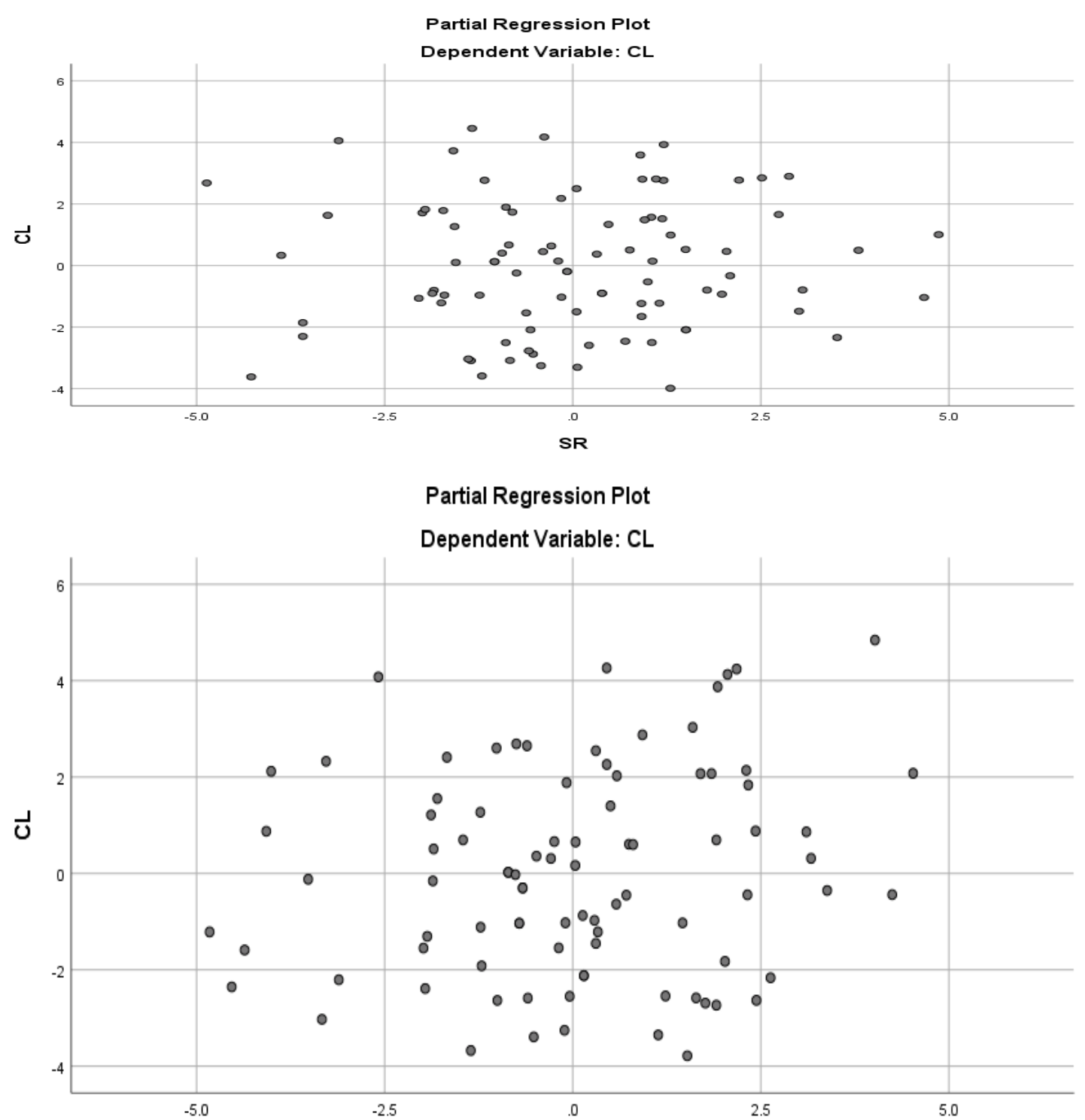

SRL 


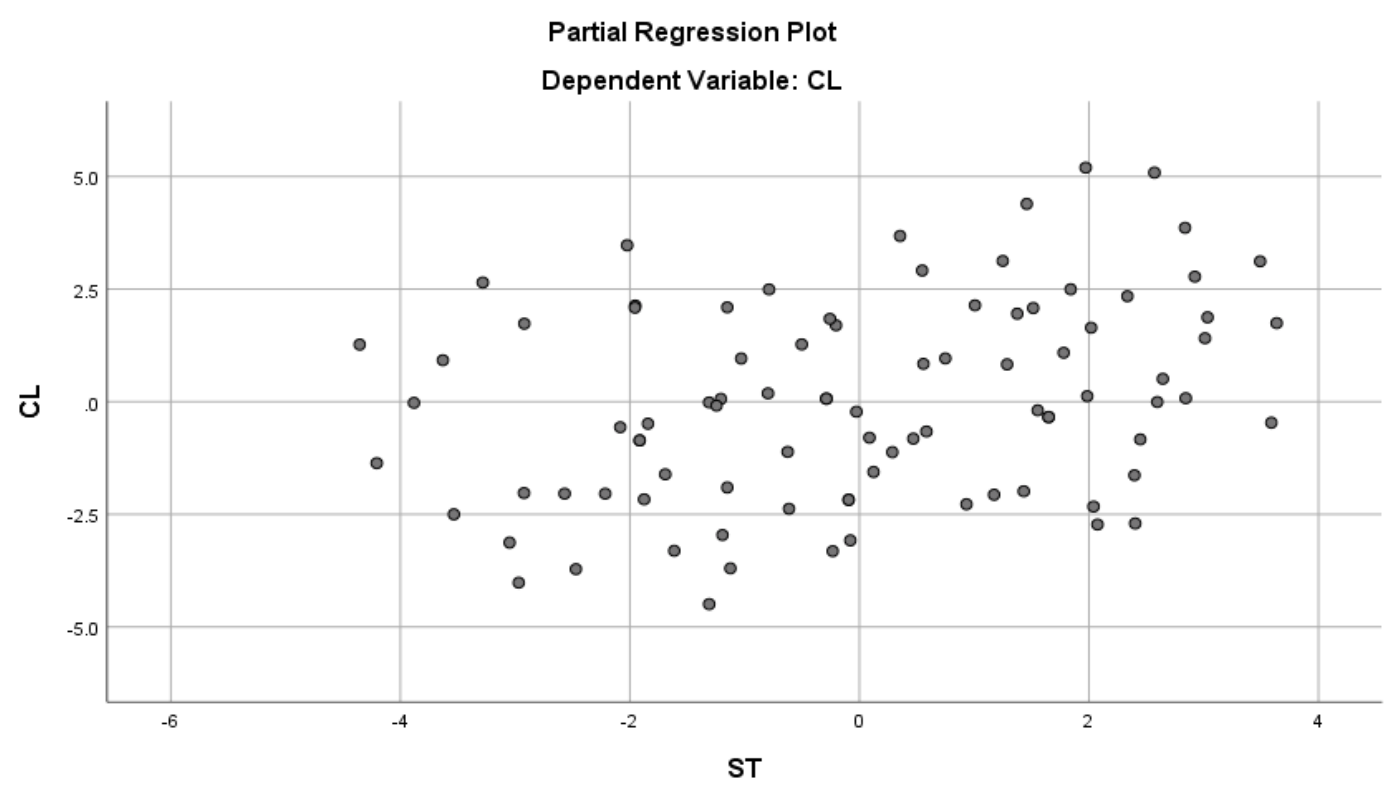

\section{QUESTIONNAIRE RESULT:}

The results obtained from the research questionnaire are shown below.

\section{Assurance}

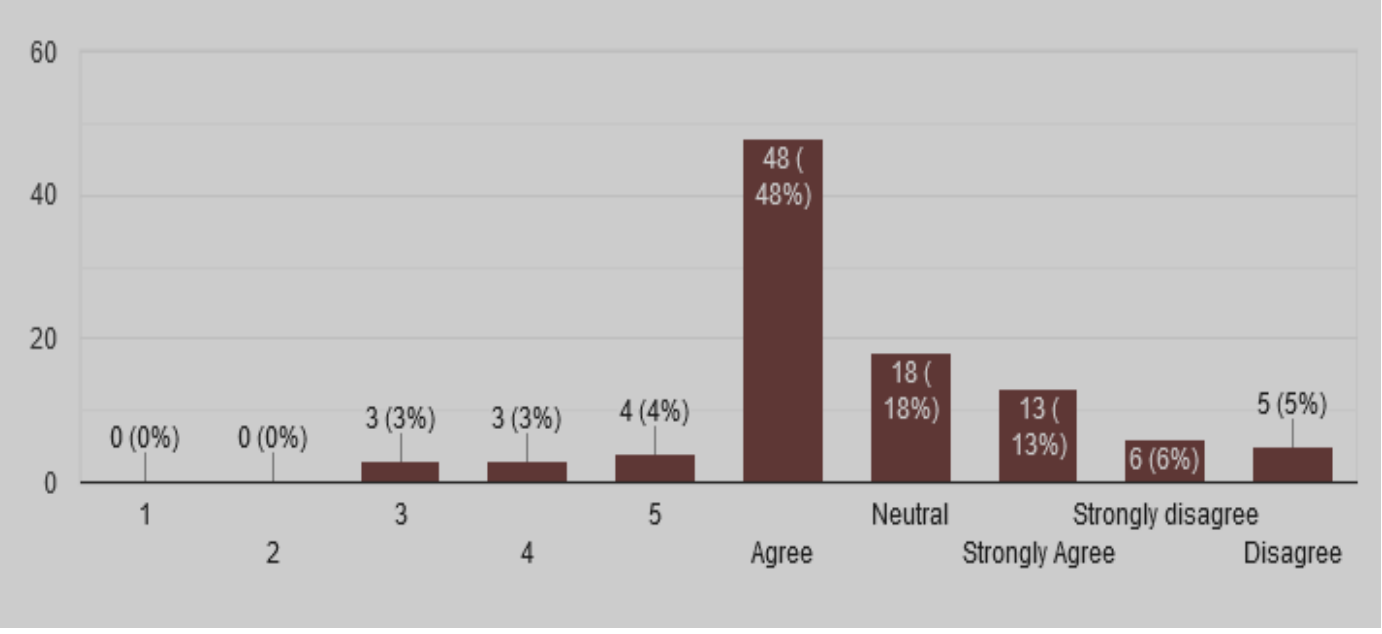




\section{Empathy}

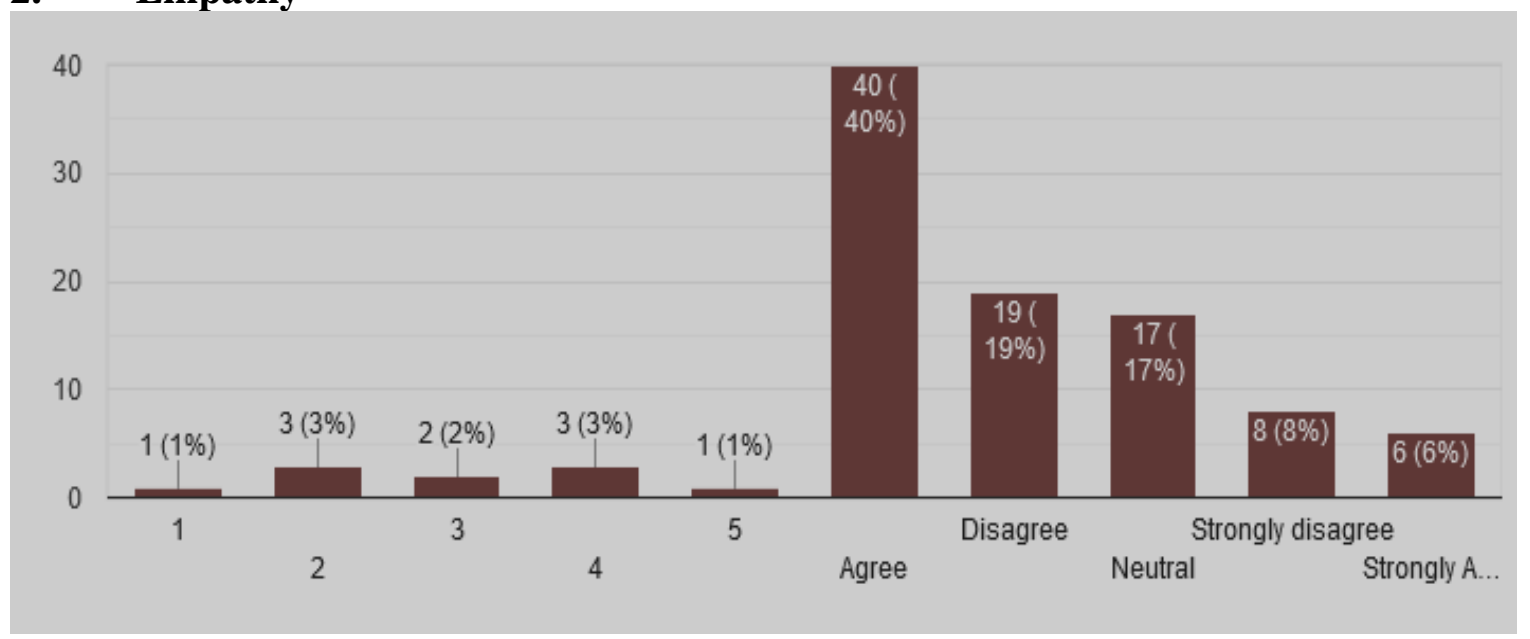

\section{Responsiveness}

60

40

20

0

0

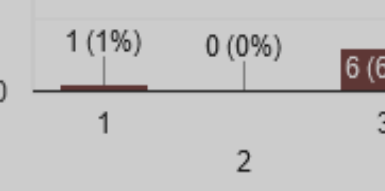

3

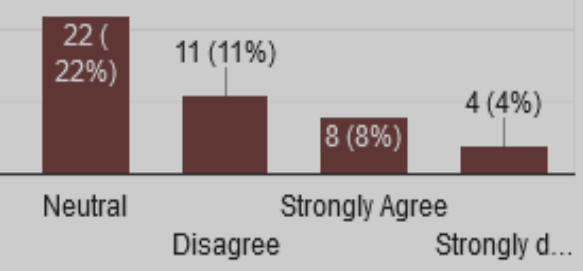




\section{Reliability}

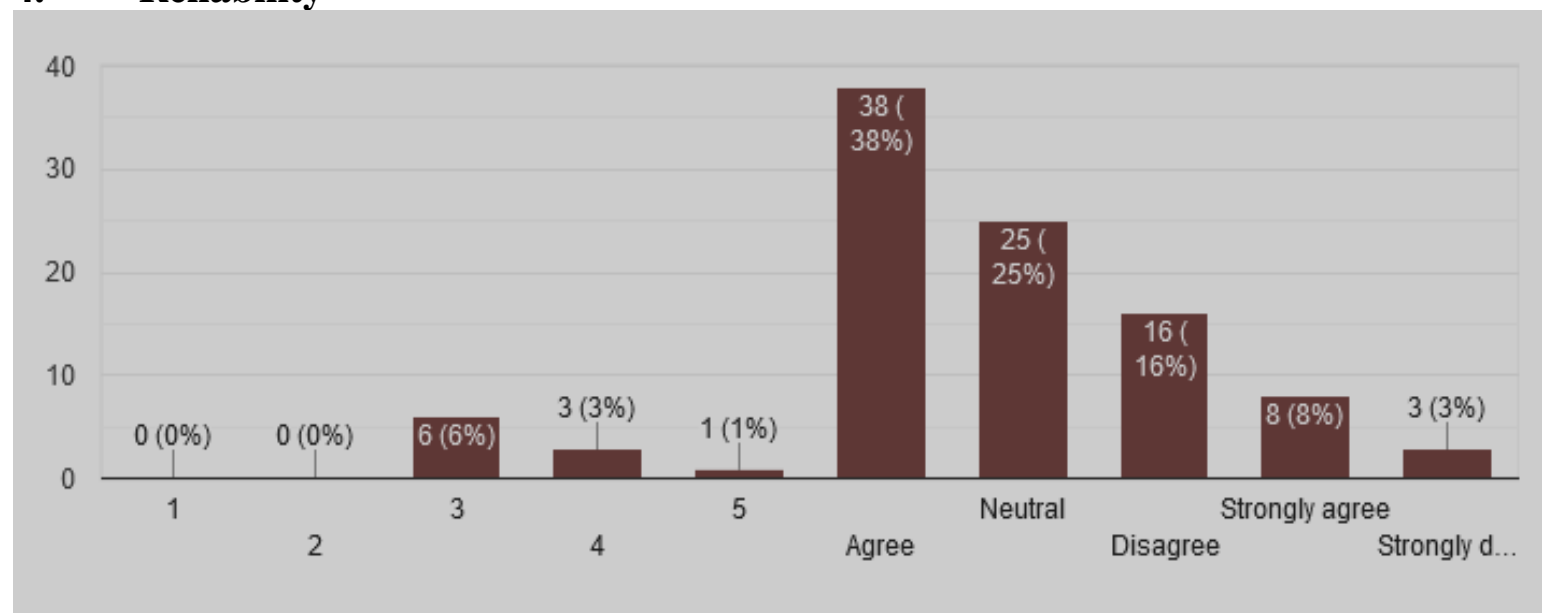

\section{The customer satisfaction}

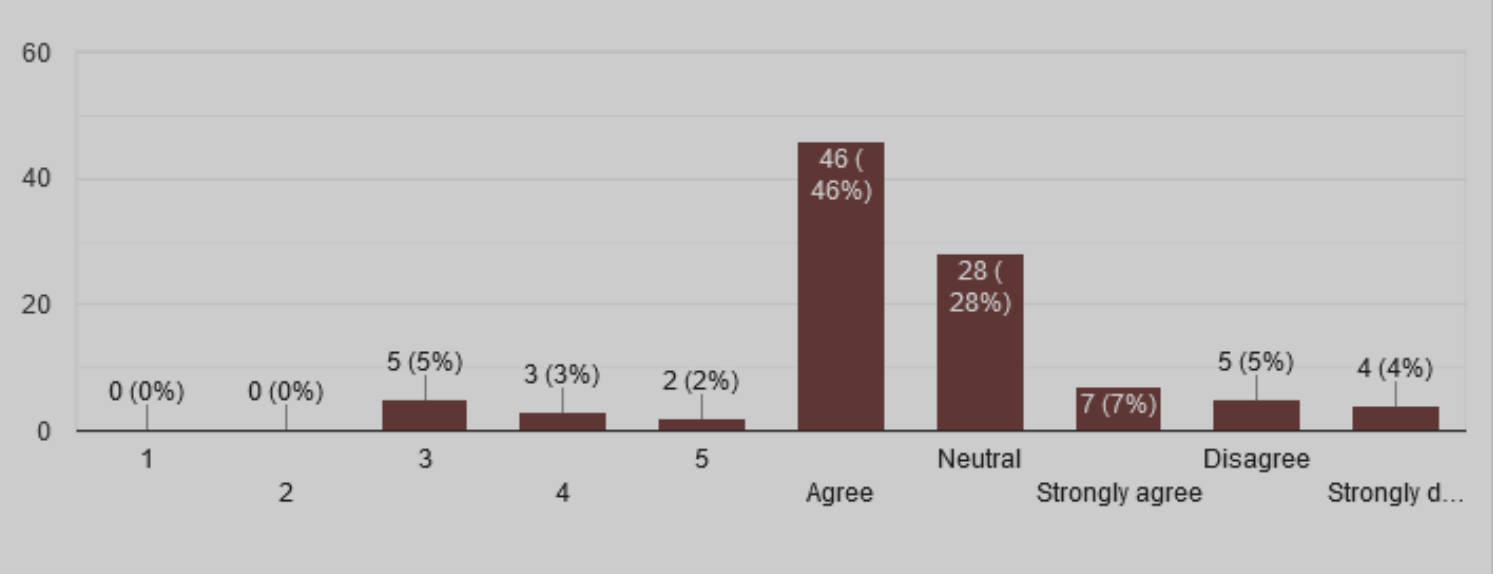




\section{The loyalty of the customer}

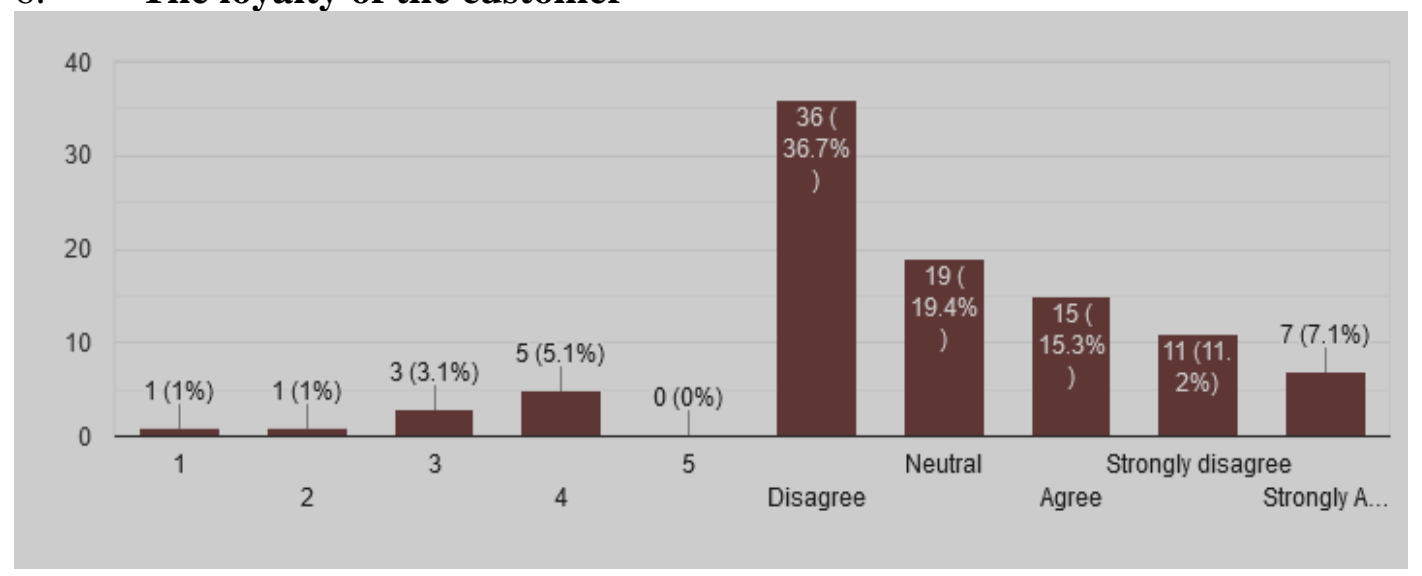

\subsubsection{Conclusion and Recommendations [ in conclusion write only how your objective got accomplished, recommendations can be given separately.]}

The view of the social network has played an important part in sociology. It has also brought significant progress in the field of economics, psychology and interdisciplinary study. Comparison has more restricted the prevalence of the social network view in IB research. Nonetheless, a rising number of works in international business give useful insights from the standpoint of the network. We have given a quick summary of this body of work to offer a feeling of some of the current topics and guidelines that explore the phenomena associated with international business at various levels using networking arguments, actions or methods. Our review and discussion are hopeful that our overview and discussion provide a strong sense of return for international business research using social network theories and techniques. International business research might thus be particularly well adapted for taking a network viewpoint on several levels or international levels, allowing them to make progress on a larger network literature and to take advantage of recent conceptual and methodological developments. Although this potential may be used in numerous ways to solve international business difficulties and increase markets for international businesses as well. Out of 200 questionnaires distributed, the results obtained from the research data revealed above $90 \%$ of the customers are loyal to services provided by the banking sector in Karachi, Pakistan, reliability, tangibility, responsiveness, empathy, and validity have a positive influence on the loyalty of the customer, while around $10 \%$ of clients are not satisfied with the quality of the service. It is also proved by the data that there is a positive facilitating impact of the customer satisfaction among reliability, tangibility, responsiveness, empathy, and 
validity with relation to the loyalty of the customer. However, assurance does not have a significant influence on customer satisfaction due to the low level of security and trust issues through online services. There are reported instances of fraudulent and cyber theft activities. The study has several limitations. First, the study utilized data from only the banking customers of Karachi and disregarded other service sectors. Second, the study has examined only selected dimensions of quality of service. Other types of service qualities include credibility, communication, security, and competence are not part of this study. Thirdly, a small sample of data has been examined due to the global covid-19 pandemic situation. Future studies could explore the impact of service quality on customer satisfaction of the banking sector in Pakistan and may include other sectors. 


\section{References:}

Aaker, D. A., \& Jacobson, R. (1994). The financial information content of perceived quality. Journal of marketing research, 31(2), 191-201.

Alabboodi, A. S. (2019). The effect of the customer satisfaction on the quality of service: The case of Iraqi banks. International Journal of Applied Research, 5(1), 146-152.

Al-Azzam, A. F. M. (2015). The impact of the quality of service dimensions on the customer satisfaction: A field study of Arab bank in Irbid city, Jordan. European Journal of Business and Management, 7(15), 45-53.

Alkhawaldeh, A., \& Eneizan, B. M. (2018). Factors influencing brand loyalty in the durable goods market. International Journal of Academic Research in Business and Social Sciences, 8(1), 326-339.

Alkhawaldeh, A., Al-Salaymeh, M., Alshare, F., \& Eneizan, B. M. (2017). The effect of brand awareness on brand loyalty: Mediating role of brand commitment. European Journal of Business and Management, 9(36).

Anderson, C. R., \& Zeithaml, C. P. (1984). Stage of the product life cycle, business strategy, and business performance. Academy of Management Journal, 27(1), 524.

Awan, H. M., Bukhari, K. S., \& Iqbal, A. (2011). Quality of service and the customer satisfaction in the banking sector. Journal of Islamic Marketing.

Bateson, J. E. (1985). Self-service consumer: An exploratory study. Journal of retailing.

Bolton, R. N. (1998). A dynamic model of the duration of the customer's relationship with a continuous service provider: The role of the satisfaction. Marketing Science, 17(1), 45-65. 
Bolton, R. N., \& Drew, J. H. (1991). A multistage model of the customers' assessments of the quality of service and value. Journal of consumer research, 17(4), 375-384.

Boulding, W., Kalra, A., Staelin, R., \& Zeithaml, V. A. (1993). A dynamic process model of quality of service: from expectations to behavioural intentions. Journal of marketing research, 30(1), 7-27.

Bryman, M. A. H. A. (2004). Handbook of data analysis. Sage.

Buttle, F. (1996). SERVQUAL: review, critique, research agenda. European Journal of marketing.

Buzzell, Robert Dow, Bradley T. Gale, and Bradley T. Gale. The PIMS principles: Linking strategy to performance. Simon and Schuster, 1987.

calculator.net. (n.d.). Sample Size Calculator. Retrieved from calculator.net: https://www.calculator.net/sample-sizecalculator.html type $=1 \& \mathrm{cl}=90 \& \mathrm{ci}=5 \& \mathrm{pp}=50 \& \mathrm{ps}=20000000 \& \mathrm{x}=72 \& \mathrm{y}=17$

Caruana, A. (2002). Service the loyalty. European Journal of Marketing. 36(7/8):811-28.

Chen, C. F., \& Tsai, D. (2007). How destination image and evaluative factors affect behavioural intentions?. Tourism Management, 28(4), 1115-1122.

Choi, T. Y., \& Chu, R. (2001). Determinants of hotel guests' satisfaction and repeat patronage in the Hong Kong hotel corporation. International Journal of Hospitality Management, 20(3), 277-297.

Chow, C. C., \& Luk, P. (2005). A strategic quality of service approach using analytic hierarchy process. Managing quality of service: an international journal.

Cronin Jr, J. J., \& Taylor, S. A. (1992). Measuring quality of service: a reexamination and extension. Journal of Marketing, 56(3), 55-68.

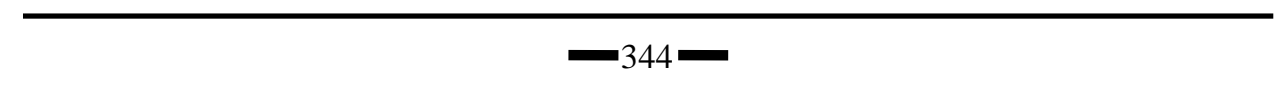


Crosby, F. (1984). The denial of personal discrimination. American behavioural scientist, 27(3), 371-386.

Ding, S., Wang, Z., Wu, D., \& Olson, D. L. (2017). Utilizing the customer satisfaction in ranking prediction for personalized cloud service selection. Decision Support Systems, 93, 1-10.

Dyer, P., Gursoy, D., Sharma, B., \& Carter, J. (2007). Structural modeling of resident perceptions of tourism and associated development on the Sunshine Coast, Australia. Tourism Management, 28(2), 409-422.

Flick, U. (2015). Qualitative inquiry - 2.0 at 20? Developments, trends, and challenges for the politics of research. Qualitative Inquiry, 21(7), 599-608.

Garvin, D. A. (1983). Spin-offs and the new firm formation process. California management review, 25(2), 3-20.

Gera, R. (2011). Modeling the service antecedents of favorable and unfavorable behaviour intentions in life insurance services in India. International Journal of Quality and Service Sciences.

Ghobadian, A., Speller, S., \& Jones, M. (1994). Quality of service. International journal of quality \& reliability management.

Gronholdt, L., Martensen, A., \& Kristensen, K. (2000). The Relationship between The customer satisfaction and The loyalty, Abingdon. Total Quality Management.

Grönroos, C. (2000). Creating a relationship dialogue: communication, interaction, and value. The marketing review, 1(1), 5-14.

Grönroos, C. (2000). Service management and marketing: A customer relationship management approach.

Hax, AC, \& Wilde, DL (2003). The Delta Model-A New Strategic Framework. Journal of Strategic Management Education, 1-14. 
Hollensen, S. (2019). Marketing management: A relationship approach. Pearson Education.

Homburg, C., Droll, M., \& Totzek, D. (2008). The customer prioritization: does it pay off, and how should it be implemented? Journal of Marketing, 72(5), 110-130.

Hu, P. J. H., Hu, H. F., Wei, C. P., \& Hsu, P. F. (2016). Examining firms' green information technology practices: A hierarchical view of key drivers and their effects. Journal of Management Information Systems, 33(4), 1149-1179.

Ibáñez, A. M., \& Moya, A. (2006). The impact of intra-state conflict on economic welfare and consumption smoothing: Empirical evidence for the displaced population in Colombia. Available at SSRN 1392415.

Jeong, M. S., Cha, J. E., \& Jang, D. H. (2016). Impact of the quality of service of horseback riding experience on the customer satisfaction and the loyalty-In case of the Jangsu horse riding experience course. Journal of Korean Society of Rural Planning, 22(2), 131-140.

Junaidi, I. (2018, December 20). 1,244 online bank fraud cases reported in 10 months, Senate told. Retrieved from Dawn: https://www.dawn.com/news/1452467

Juran, J. M. (1988). Juran on planning for quality. Collier Macmillan.

Kashif, M., Awang, Z., Walsh, J., \& Altaf, U. (2015). I'm loving it but hating the US. British Food Journal.

Khan, M. M., \& Fasih, M. (2014). Impact of quality of service on the customer satisfaction and the loyalty of the customer: Evidence from the banking sector. Pakistan Journal of Commerce and Social Sciences (PJCSS), 8(2), 331-354.

Kheng, L. L., Mahamad, O., \& Ramayah, T. (2010). The impact of the quality of service on the loyalty of the customer: A study of banks in Penang, Malaysia. International journal of marketing studies, 2(2), 57.

Kotler, P., \& Armstrong, G. (1996). Principles of marketing. International edition. 
Kristensen, K., Kanji, G. K., \& Dahlgaard, J. J. (1992). On the measurement of the customer satisfaction. Total Quality Management, 3(2), 123-128.

Loke, S. P., Taiwo, A. A., Salim, H. M., Downe, A. G., \& PETRONAS, U. T. (2011). Quality of service and the customer satisfaction in a telecommunication service provider. In International conference on financial management and economics (Vol. 11, No. 2, pp. 23-29).

Malhotra, K. (2010). Autoregressive multifactor APT model for US Equity Markets.

Matar, A., \& Eneizan, B. M. (2018). Determinants of financial performance in the industrial firms: Evidence from Jordan. Asian Journal of Agricultural Extension, Economics \& Sociology, 1-10.

McColl-Kennedy, J., \& Schneider, U. (2000). Measuring the customer satisfaction: why, what, and how. Total quality management, 11(7), 883-896.

Mostafa, A. A., \& Eneizan, B. (2018). Factors affecting acceptance of mobile banking in developing countries. International Journal of Academic Research in Business and Social Sciences, 8(1), 340-351.

Muturi, D., Sagwe, J., Cheruiyot, T. K., \& Maru, L. C. (2013). Quality of service and relative performance of public universities in East Africa. The TQM Journal. 25(5):533-546

Muyeed, M. A. (2012). The customer perception on quality of service in retail banking in developing a countries-a case study. International Journal of Marketing Studies, 4(1), 116.

Ndubisi, N. O. (2006). A structural equation modeling of the antecedents of relationship quality in the Malaysian banking sector. Journal of Financial Services Marketing, 11(2), 131-141. 
Ndubisi, N. O., \& Wah, C. K. (2005). Factorial and discriminant analyses of the underpinnings of relationship marketing and the customer satisfaction. International journal of bank marketing.

Oh, H., \& Kim, K. (2017). The customer satisfaction, quality of service, and the customer value: years 2000-2015. International Journal of Contemporary Hospitality Management.

Oldfield, B. M., \& Baron, S. (2000). Student perceptions of quality of service in a UK university business and management faculty. Quality Assurance in education.

Oliver R L (1981), "Measurement and Evaluation of The satisfaction Process in Retail Setting", Journal of Retailing, Vol. 57, No. 3, pp. 18-48.

Parasuraman, A., Zeithaml, V. A., \& Berry, L. L. (1985). A conceptual model of quality of service and its implications for future research. Journal of Marketing, 49(4), 41-50.

Parasuraman, A., Zeithaml, V. A., \& Berry, L. L. (1988). SERVQUAL: A multiple-item scale for measuring consumer PERC. Journal of retailing, 64(1), 12.

Paul, J., Mittal, A., \& Srivastav, G. (2016). Impact of quality of service on the customer satisfaction in private and public sector banks. International Journal of Bank Marketing.

Phillips, L. W., Chang, D. R., \& Buzzell, R. D. (1983). Product quality, cost position and business performance: a test of some key hypotheses. Journal of Marketing, 47(2), 26-43.

Quinn, M., \& Humble, J. (1993). Using service to gain a competitive edge-The PROMPT approach. Long Range Planning, 26(2), 31-40.

Raza, S. A., Jawaid, S. T., \& Hassan, A. (2015). Internet banking and the customer satisfaction in Pakistan. Qualitative Research in Financial Markets. 7(1):24-36.

Reichheld, F. F., \& Sasser, W. E. (1990). Zero defeofions: Quality comes to services. Harvard business review, 68(5), 105-111. 
Ringle, C. M., Wende, S., \& Becker, J. M. (2015). SmartPLS 3. Retrieved from SmartPLS: http://www.smartpls.com

Rust, R. T., \& Zahorik, A. J. (1993). The customer satisfaction, the customer retention, and market share. Journal of retailing, 69(2), 193-215.

Saeidi, S. P., Rasli, A. B. M., Saeidi, P., Saaeidi, S. A., \& Saeidi, S. P. (2017). How Quality of service Results in The customer satisfaction of Large-Scale Retailers in Malaysia. Advanced Science Letters, 23(9), 9050-9054.

Sasser, W. E., Schlesinger, L. A., \& Heskett, J. L. (1997). Service profit chain. Simon and Schuster.

Siddiqi, K. O. (2011). Interrelations between the quality of service attributes, the customer satisfaction, and the loyalty of the customer in the retail banking sector in Bangladesh. International journal of business and management, 6(3), 12.

Taylor, S. A., Celuch, K., \& Goodwin, S. (2004). The importance of brand equity to the loyalty of the customer. Journal of product $\&$ brand management.

Van Looy, B., Gemmel, P., \& Dierdonck, R. (Eds.). (2003). Services management: An integrated approach. Pearson Education.

Wang, Y., Lo, H. P., \& Hui, Y. V. (2003). The antecedents of quality of service and product quality and their influences on bank reputation: evidence from the banking corporation in China. Managing Quality of service: An International Journal.

Woo, J., Kainat, M., \& Adeeb, S. (2017, July). Development of a Profile Matching Criteria to Model Dents in Pipelines Using Finite Element Analysis. In Pressure Vessels and Piping Conference (Vol. 57984, p. V005T11A004). American Society of Mechanical Engineers.

Yang, Z., \& Fang, X. (2004). Online quality of service dimensions and their relationships with the satisfaction. International journal of service corporation management. 
Yeung, M. C., Ging, L. C., \& Ennew, C. T. (2002). The customer satisfaction and profitability: A reappraisal of the nature of the relationship. Journal of Targeting, Measurement, and Analysis for Marketing, 11(1), 24-33.

Yousuf, K. (2017). The Impact of Quality of service on The customer satisfaction in the Banking Sector of Karachi. Market Forces, 12(1).

Zainal, N. S., Shaharudin, M. R., \& Jusoff, K. (2010). Quality of service perceptions between cooperative and Islamic Banks of Britain. American Journal of Economics and Business Administration, 2(1), 1-5.

Zeithaml, V. A., Bitner, M. J., \& Gremler, D. D. (2018). Services marketing: Integrating the customer focus across the firm. McGraw-Hill Education. 